\title{
Reversal effect of bufalin on multidrug resistance in human hepatocellular carcinoma BEL-7402/5-FU cells
}

\author{
WEI GU* , LONG LIU* , FAN-FU FANG, FENG HUANG, BIN-BIN CHENG and BAI LI \\ Department of Traditional Chinese Medicine, Changhai Hospital, \\ Second Military Medical University, Shanghai 200433, P.R. China
}

Received August 8, 2013; Accepted September 13, 2013

DOI: $10.3892 /$ or.2013.2817

\begin{abstract}
Multidrug resistance (MDR) is a major obstacle to chemotherapy in patients with hepatocellular carcinoma (HCC). To overcome MDR and improve chemotherapeutic efficacy, novel reversal agents with higher efficacy and lower toxicity are urgently needed for HCC. The present study was designed to examine the potential reversal activity of bufalin, a toxic ligand isolated from the traditional Chinese medicine 'Chansu' and to elucidate the possible related mechanisms. A multidrug-resistant HCC cell line, BEL-7402/5-FU, was used as the cell model. The working concentration of bufalin as an effective reversal agent, and the cell viability in the reversal experiments were determined by MTT assay. The effects of bufalin at a non-cytotoxic dose on cell cycle distribution, apoptosis and drug efflux pump activity were measured by flow cytometry. Qualitative observation of apoptosis was also carried out by confocal microscopy. Furthermore, the effects of bufalin on the expression of potential genes involved in MDR of BEL-7402/5-FU cells, including thymidylate synthase (TS), P-glycoprotein (P-gp), multidrug resistance protein 1 (MRP1), B-cell lymphoma-extra large (Bcl-xL) and Bcl-2-associated $X$ protein (Bax), were determined using realtime PCR and western blot analysis. The results showed that bufalin at a concentration of $1 \mathrm{nM}$ enhanced the chemosensitivity of BEL-7402/5-FU cells to 5-FU with a reversal fold of 3.8 which was similar to that of $1 \mu \mathrm{M}$ verapamil. Bufalin significantly arrested the cell cycle at the $G_{0} / G_{1}$ phase, induced apoptosis through an increase in the Bax/Bcl-xL ratio, inhibited drug efflux pump activity via downregulation of MRP1, and reduced the expression of TS in BEL-7402/5-FU cells. The present study revealed that bufalin effectively reversed MDR in BEL-7402/5-FU cells through multiple pathways. The
\end{abstract}

Correspondence to: Dr Bai Li, Department of Traditional Chinese Medicine, Changhai Hospital, Second Military Medical University, 168 Changhai Road, Shanghai 200433, P.R. China

E-mail: libai9@126.com

*Contributed equally

Key words: apoptosis, bufalin, hepatocellular carcinoma, multidrug resistance, ATP-binding cassette transporters combination of bufalin with cytotoxic drugs may serve as a promising strategy for the chemotherapy of HCC.

\section{Introduction}

Hepatocellular carcinoma (HCC) still remains a severe health issue in China. More than 402,000 new cases of HCC (14.3\% of all cancer cases) and 372,000 deaths (19.0\% of all cancer-related deaths) were estimated to have occurred in 2008 in China. $\mathrm{HCC}$ is the third most common type of cancer and the third leading cause of cancer-related mortality among the Chinese (1). Although the poor outcome of HCC is mainly attributed to the high rate of advanced stage disease at diagnosis, the poor response of HCC cells to cytotoxic drugs also plays a critical role. The chemoresistance of HCC cells, particularly in its multiple form (multidrug resistance, MDR), either intrinsic or acquired, is a major obstacle to the successful management of HCC (2-4).

To improve the efficacy of cytotoxic drugs for HCC, a few compounds have been utilized as MDR reversal agents to overcome the chemoresistance of HCC cells (5). However, these compounds frequently showed intolerable toxicity when they were administered at an effective dose in clinical trials $(6,7)$. These defects have limited their application in clinical settings. Thus, it is urgent to develop novel reversal agents with higher efficacy and lower toxicity to overcome MDR of HCC.

'Chansu', a traditional Chinese medicine composed of dried toad venom or dried secretion from the skin glands of Bufo gargarizans or B. melanostictus, has been used to treat liver cancer in China for several hundreds of years (8). Bufalin, a toxic ligand isolated from 'Chansu', has been confirmed as one of the most active components for the treatment of liver cancer. Moreover, bufalin was found to exhibit activity for inducing differentiation and apoptosis in vitro for leukemia $(9,10)$ and cancers of the prostate (11) and stomach (12). Our previous study revealed that bufalin exhibited significant antitumor activity in an orthotopic transplantation model of human HCC in nude mice with no marked toxicity and was able to induce apoptosis of transplanted HCC cells (13). However, little is known concerning the possible effect of bufalin on MDR of HCC. Thus, in the present study, the potential anti-MDR activity of bufalin was evaluated by using a multidrug-resistant human HCC cell line, and the possible mechanisms involving the reversal effect of bufalin were determined. 


\section{Materials and methods}

Drugs and reagents. Bufalin was purchased from Sigma Chemical Co. (St. Louis, MO, USA) and initially dissolved in anhydrous alcohol before serial dilution with RPMI1640 medium. 5-Fluorouracil (5-FU) was obtained from Shanghai Xudong Haipu Pharmaceutical Co. (Shanghai, China). Verapamil was purchased from Shanghai Harvest Pharmaceutical Co. (Shanghai China), and it was used as a positive control reversal agent. The primary antibodies against human thymidylate synthase (TS), P-glycoprotein (P-gp), multidrug resistance protein 1 (MRP1), B-cell lymphomaextra large (Bcl-xL) and $\mathrm{Bcl}-2$-associated $\mathrm{X}$ protein $(\mathrm{Bax})$ were all purchased from Santa Cruz Biotechnology Inc. (Santa Cruz, CA, USA).

Cell lines and cell culture. BEL-7402/5-FU, a 5-FU-resistant human HCC cell line with a moderate MDR phenotype (resistance index $=18$ ), was successfully established by imitating the administration pattern of clinical chemotherapy in our previous study (14). The BEL-7402/5-FU cells were able to grow and passage steadily in medium containing 5-FU at a concentration of $50 \mu \mathrm{M}$ and were used as the cell model in the present study. The cells were cultured in RPMI-1640 medium (HyClone), supplemented with 10\% fetal bovine serum (FBS; Sijiqing, China) at $37^{\circ} \mathrm{C}$ in a humidified atmosphere containing $5 \% \mathrm{CO}_{2}$.

Cell viability assay. The effect of drugs on cell viability was quantified using the 3-[4,5-dimethyl-2-thiazol]-2,5-diphenyltetrazolium bromide (MTT) assay. Cells in the exponential growth phase were trypsinized and seeded in 96-well plates and then treated with the scheduled treatment of drugs. Medium without drug was added to the control and blank wells. After incubation for the scheduled time, $10 \mu \mathrm{l}$ MTT (Amresco, Boston, MA, USA) at a concentration of $5 \mathrm{mg} / \mathrm{ml}$ was added for $4 \mathrm{~h}$ at $37^{\circ} \mathrm{C}$. Then culture medium was removed, and the insoluble formazan crystals were dissolved in $150 \mu \mathrm{l}$ of dimethyl sulfoxide (DMSO). The absorbance (optical density, OD) was measured at $490 \mathrm{~nm}$ of the wavelength using a microplate reader. The cell growth inhibition rate was calculated using the following formula: Growth inhibition rate $=(O D$ value of control - OD value of test)/(OD value of control - OD value of blank) x $100 \%$. The 10 and $50 \%$ inhibitory concentrations $\left(\mathrm{IC}_{10}\right.$ and $\left.\mathrm{IC}_{50}\right)$ were estimated by probit analysis.

$M D R$ reversal assay. A reversal agent should exhibit neither an inhibitory nor a toxic effect to tumor cells when administered. In the present study, the $\mathrm{IC}_{10}$ value of bufalin alone for BEL-7402/5-FU cells was calculated,and a concentration $(1 \mathrm{nM})$ lower than the $\mathrm{IC}_{10}$ value was designated as the reversal concentration of bufalin in the following experiments.

BEL-7402/5-FU cells were plated in 96-well plates and allowed to grow for $12 \mathrm{~h}$. The cells were then pretreated with $1 \mathrm{nM}$ bufalin for an incubation of $2 \mathrm{~h}$, followed by treatment with serial dilutions of 5-FU for $48 \mathrm{~h}$. Cells treated with 5-FU alone and verapamil alone were considered as the controls. By using the MTT assay as described above, the $\mathrm{IC}_{50}$ of each treatment was calculated. The reversal fold $(\mathrm{RF})$ was defined as the ratio between the $\mathrm{IC}_{50}$ value of 5-FU alone to that of 5-FU combined with bufalin, and RF was used as the index of MDR-reversal activity in the present study.

Cell cycle assay. BEL-7402/5-FU cells were seeded into 6-well plates and incubated for $24 \mathrm{~h}$. Cells were then treated with bufalin at a final concentration of $1 \mathrm{nM}$ for $48 \mathrm{~h}$. The cells treated with medium without bufalin were regarded as the control. After treatment, cells were trypsinized, pelleted, washed, diluted and then fixed by suspending the cells in ethanol at $4^{\circ} \mathrm{C}$ overnight. After washing and centrifugation, cells were incubated with $400 \mu \mathrm{l}$ propidium iodide (PI) $(50 \mu \mathrm{g} /$ $\mathrm{ml}$; Sigma) and $10 \mu 1$ DNase-free RNase ( $1 \mathrm{mg} / \mathrm{ml}$; Sigma) in phosphate-buffered saline (PBS) in the dark for $30 \mathrm{~min}$. The cells were measured using a FACScan flow cytometer (BD Biosciences, San Jose, CA, USA), and the data were analyzed using ModFit LT for Mac version 3.0 software (Verity Software House, Topsham, ME, USA).

Apoptosis assay. Quantitative assessment of apoptosis was carried out using the Annexin V-FITC apoptosis detection kit (Bender MedSystems, San Bruno, CA, USA). Briefly, BEL-7402/5-FU cells were seeded directly into 6-well plates and then incubated for $36 \mathrm{~h}$. Cells were then treated with bufalin at a final concentration of $1 \mathrm{nM}$ for $24 \mathrm{~h}$. Following bufalin treatment, cells were trypsinized, pelleted, washed and diluted. Annexin V-FITC was added to the cell suspension at a dilution of 1:40, and the mixture was incubated for $10 \mathrm{~min}$ at room temperature. The cells were washed, resuspended and incubated with propidium iodide (PI) at a final concentration of $1 \mu \mathrm{g} / \mathrm{ml}$. The cells were then analyzed by using flow cytometry.

Qualitative observation of apoptosis was also carried out using the Annexin V-FITC apoptosis detection kit as mentioned above, and the cells coated on coverslips were observed using a Leica TCS SPE confocal microscope (Leica Microsystems GmbH, Mannheim, Germany).

Intracellular ADM accumulation assay. Intracellular accumulation of adriamycin (ADM) was determined by flow cytometry as an index of drug efflux pump activity (14). Cells were plated in 6-well plates and cultured for $36 \mathrm{~h}$. Bufalin was then added at a final concentration of $1 \mathrm{nM}$ for $2 \mathrm{~h}$ followed by the addition of ADM at a final concentration of $20 \mu \mathrm{g} / \mathrm{ml}$ for $2 \mathrm{~h}$. Cells were harvested and subjected to flow cytometry with excitation measured at $488 \mathrm{~nm}$ and emission measured at $575 \mathrm{~nm}$. The data were analyzed using CellQuest software (BD Biosciences, San Jose, CA, USA).

Rhodamine 123 retention assay. Intracellular retention of Rhodamine 123 (Rh-123) was determined by flow cytometry as a functional index of P-gp activity (14). Cells were plated in 6-well plates followed by culture for $36 \mathrm{~h}$. Bufalin was then added at a final concentration of $1 \mathrm{nM}$ for $2 \mathrm{~h}$ and subsequently Rh-123 (Sigma) was added at a final concentration of $0.25 \mu \mathrm{g} / \mathrm{ml}$ for $30 \mathrm{~min}$ at $37^{\circ} \mathrm{C}$. Cells were harvested and immediately subjected to flow cytometric analysis to measure the Rhodamine fluorescence at an excitation wavelength of $488 \mathrm{~nm}$ and an emission wavelength of $530 \mathrm{~nm}$. 
Fluorescein accumulation assay. Intracellular accumulation of fluorescein (FLU) was measured by flow cytometry as a functional index of MRP1 activity (14). Cells were plated in 6 -well plates and cultured for $36 \mathrm{~h}$. Bufalin was then added at a final concentration of $1 \mathrm{nM}$ for $2 \mathrm{~h}$, followed by the addition of FLU (Sigma) at a final concentration of $100 \mu \mathrm{M}$ for $3 \mathrm{~h}$ at $37^{\circ} \mathrm{C}$. Cells were harvested and intracellular fluorescence of FLU was immediately measured with flow cytometry at an excitation wavelength of $488 \mathrm{~nm}$ and an emission wavelength of $520 \mathrm{~nm}$.

Reverse transcription and real-time quantitative PCR. BEL-7402/5-FU cells were plated in 6-well plates and cultured for $24 \mathrm{~h}$. Bufalin was added at a final concentration of $1 \mathrm{nM}$ for $48 \mathrm{~h}$. Total RNA was extracted from the cells using TRIzol reagent (Invitrogen, Carlsbad, CA, USA) according to the manufacturer's protocol. The concentration and purity of the extracted total RNA were computed by the OD values at 260 and $280 \mathrm{~nm}$. Reverse transcription (RT) was carried out using a PrimeScript ${ }^{\mathrm{TM}}$ RT reagent kit (Takara, Shiga, Japan) following the instructions of the manufacturer. The reaction was run in an ABI 2720 thermal cycler (Applied Biosystems, Foster City, CA, USA) for $60 \mathrm{~min}$ at $37^{\circ} \mathrm{C}$ and for $5 \mathrm{sec}$ at $85^{\circ} \mathrm{C}$.

Real-time quantitative PCR was performed with an ABI PRISM $^{\circledR}$ 7900HT sequence detection system (Applied Biosystems) using the SYBR ${ }^{\circledR}$ Premix Ex Taq ${ }^{\text {TM }}$ II (Perfect Real-Time) kit (Takara) as described by the manufacturer. The total volume of reaction was $50 \mu \mathrm{l}$, which contained $5 \mu \mathrm{l}$ of cDNA template $(100 \mathrm{ng}), 25 \mu 1$ of $2 \mathrm{X}$ Power SYBR ${ }^{\circledR}$ Green PCR Master Mix, $1 \mu \mathrm{l}$ forward primer of $10 \mu \mathrm{M}, 1 \mu \mathrm{l}$ reverse

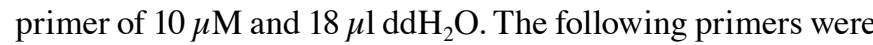
used to amplify the target genes: TS, 5'-CCAGTGGAGGCAT TTTGGG-3' (forward) and 5'-CGTCAGGGTTGGTTTTGA TGG-3' (reverse); MDR1, 5'-ATATCAGCAGCCCACAT CAT-3' (forward) and 5'-GAAGCACTGGGATGTCCGGT-3' (reverse); MRP1, 5'-CTTGGCCACGTACATTAACATGAT-3' (forward) and 5'-CCGATTGTCTTTGCTCTTCATG-3' (reverse); Bcl-xL, 5'-TGAATCGGAGATGGAGACCC-3' (forward) and 5'-TCAAACTCGTCGCCTGCC-3' (reverse); Bax, 5'-CTTTTGCTTCAGGGTTTCATC-3' (forward) and 5'-ATCATCCTCTGCAGCTCCAT-3' (reverse); and $\beta$-actin, 5'-TGTTACAGGAAGTCCCTTGC-3' (forward) and 5'-AAG CAATGCTATCACCTCCC-3' (reverse). All primers were synthesized by Sangon Biotech Co., Ltd. (Shanghai, China). After an initial denaturation at $95^{\circ} \mathrm{C}$ for $30 \mathrm{sec}$, PCR was performed for 40 cycles of $95^{\circ} \mathrm{C}$ for $5 \mathrm{sec}$ and $60^{\circ} \mathrm{C}$ for $30 \mathrm{sec}$. All samples were run in triplicate, and data were analyzed by use of the corresponding software. The specificity of amplification was confirmed by analyzing the dissociation curves. The relative expression of each target gene was normalized to $\beta$-actin expression and estimated as values of $2^{-\Delta \Delta \mathrm{Ct}}$.

Protein extraction and western blot analysis. BEL-7402/5-FU cells were plated in 6-well plates and cultured for $24 \mathrm{~h}$. Bufalin was added at a final concentration of $1 \mathrm{nM}$ for $48 \mathrm{~h}$. The cells were lysed with RIPA lysis buffer (Beyotime Institute of Biotechnology, Haimen, China) containing $1 \mathrm{mM}$ phenylmethylsulfonyl fluoride (PMSF) for $15 \mathrm{~min}$, followed by centrifugation at $20,000 \mathrm{x}$ g for $15 \mathrm{~min}$ at $4^{\circ} \mathrm{C}$. The concentrations of these protein samples were determined using an enhanced BCA protein assay kit (Beyotime Institute of Biotechnology) according to the manufacturer's protocol. The protein samples were mixed with loading buffer, boiled for $10 \mathrm{~min}$ and then separated through sodium dodecyl sulfate polyacrylamide gel electrophoresis (SDS-PAGE). Proteins were transferred to PVDF membranes (Millipore, Bedford, MA, USA) and blocked with 5\% non-fat dry milk in TBST buffer for $1 \mathrm{~h}$ at room temperature. The membranes were then immunoblotted with mouse anti-human TS monoclonal antibody (sc-33679; 1:500), mouse anti-human P-gp monoclonal antibody (sc-55510; 1:500), goat anti-human MRP1 polyclonal antibody (sc-7773; 1:500), mouse anti-human Bcl-xL monoclonal antibody (sc-8392; 1:500), mouse antihuman Bax monoclonal antibody (sc-20067; 1:500) and goat anti-human $\beta$-actin polyclonal antibody (sc-1616; 1:1000) in $5 \%$ milk/TBST at $4^{\circ} \mathrm{C}$ overnight. The membranes were then washed and incubated with horseradish peroxidase (HRP)conjugated anti-mouse or anti-goat secondary antibodies (Beyotime Institute of Biotechnology) at a dilution of 1:5,000 for $1 \mathrm{~h}$ at room temperature. The membranes were washed extensively and the signals were detected using an enhanced chemiluminescence detection system (Beyotime Institute of Biotechnology). Imaging was performed with a ChemiDoc ${ }^{\mathrm{TM}}$ XRS+ system (Bio-Rad Laboratories), and the bands were quantified using Image $\mathrm{Lab}^{\mathrm{TM}}$ software (version 2.0; Bio-Rad Laboratories).

Statistical analysis. Each experiment was performed independently at least three times and an individual experiment was performed at least in triplicate. Data are expressed as means \pm standard deviation (SD). The Student's t-test was used to compare the difference between two groups. $\mathrm{P}<0.05$ was considered to indicate a statistically significant result. All analyses were run using SPSS 15.0 statistical package (SPSS Inc., Chicago, IL, USA).

\section{Results}

Bufalin enhances the chemosensitivity of BEL-7402/5-FU cells to 5-FU. The cytotoxicity of bufalin alone to both parental BEL-7402 cells and multidrug-resistant BEL-7402/5-FU cells was initially determined by MTT assay. Bufalin displayed an apparent cytotoxic effect on both cell lines in a dose- and time-dependent manner. The $\mathrm{IC}_{50}$ values of bufalin for the parental and resistant cells were $0.75 \pm 0.23$ and $0.82 \pm 0.37 \mu \mathrm{M}$ at $24 \mathrm{~h}, 0.15 \pm 0.06$ and $0.17 \pm 0.04 \mu \mathrm{M}$ at $48 \mathrm{~h}$ and $0.06 \pm 0.03$ and $0.08 \pm 0.05 \mu \mathrm{M}$ at $72 \mathrm{~h}$, respectively. The $\mathrm{IC}_{50}$ values of bufalin for both cell lines at the three time-points were so similar that no significant difference was detected $(\mathrm{P}>0.05)$. The results indicated that BEL-7402/5-FU cells were not cross-resistant to bufalin. The $\mathrm{IC}_{10}$ value of bufalin for BEL-7402/5-FU cells at $48 \mathrm{~h}$ was $1.7 \mathrm{nM}$ and consequently a concentration of $1 \mathrm{nM}$ was designated as the reversal concentration of bufalin in the following experiments of the present study.

The reversal assay showed that, for BEL-7402/5-FU cells, the $\mathrm{IC}_{50}$ values of 5-FU alone, 5-FU combined with $1 \mathrm{nM}$ bufalin, and 5-FU combined with $1 \mu \mathrm{M}$ verapamil at $48 \mathrm{~h}$ were $427.6 \pm 110.5,112.4 \pm 25.3$ and $138.7 \pm 33.7 \mu \mathrm{M}$, respectively. The RFs of $1 \mathrm{nM}$ bufalin and $1 \mu \mathrm{M}$ verapamil for BEL-7402/5-FU cells were 3.8-fold $(\mathrm{P}=0.008)$ and 3.1-fold $(\mathrm{P}=0.012)$, respec- 
A

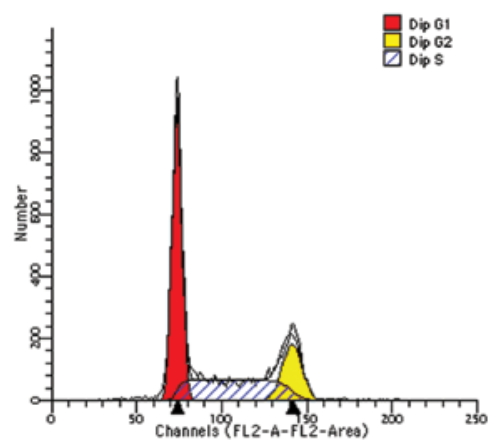

B

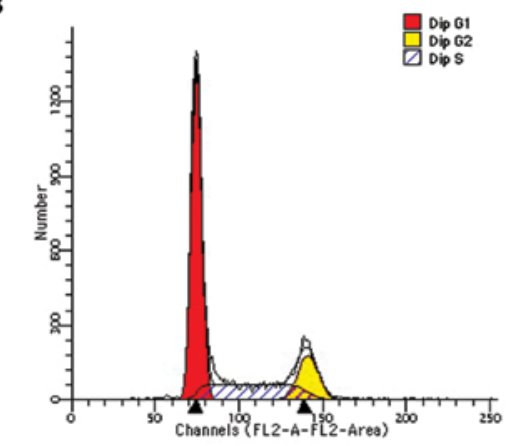

C

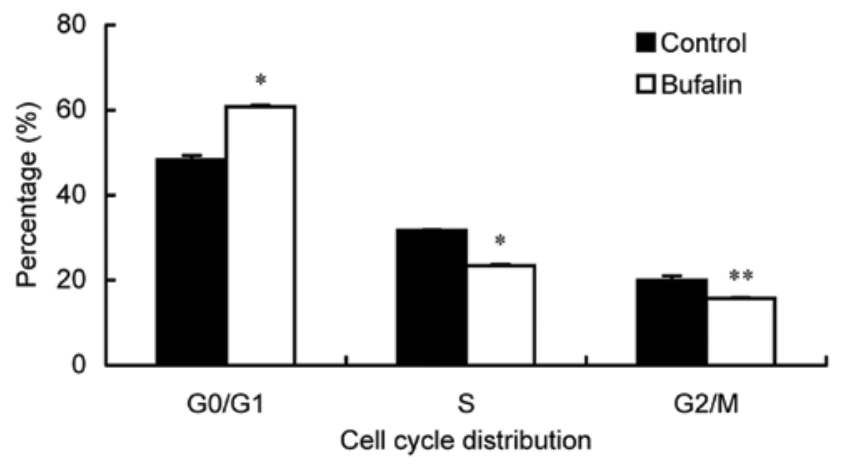

Figure 1. Bufalin induces cell cycle arrest at the $\mathrm{G}_{0} / \mathrm{G}_{1}$ phase in BEL7402/5-FU cells. The representative cell cycle distribution of (A) BEL-7402 cells without bufalin treatment and (B) bufalin-treated BEL-7402/5-FU cells is shown by flow cytometry. (C) The proportion of bufalin-treated BEL-7402/5-FU cells in the $G_{0} / G_{1}$ phase was significantly increased with a concomitant reduction in the proportion of cells in the $S$ and $\mathrm{G}_{2} / \mathrm{M}$ phases when compared with the control $\left(" \mathrm{P}<0.001,{ }^{* *} \mathrm{P}=0.002\right)$. Values were calculated by the Student's t-test. All data are presented as means $\pm \mathrm{SD}$.

tively. The results revealed that $1 \mathrm{nM}$ bufalin increased the sensitivity of BEL-7402/5-FU cells to 5-FU presenting a similar reversal activity to that of $1 \mu \mathrm{M}$ verapamil.

Bufalin arrests cell cycle progression in BEL-7402/5-FU cells. After incubation with $1 \mathrm{nM}$ bufalin for $48 \mathrm{~h}$, the proportion of BEL-7402/5-FU cells in the $G_{0} / G_{1}, S$ and $G_{2} / M$ phases was $60.8,23.4$ and $15.8 \%$, respectively. Compared to BEL-7402/5-FU cells without bufalin treatment (48.3, 31.7 and $20.0 \%$ for $G_{0} / G_{1}, S$ and $G_{2} / M$ phases, respectively), bufalin resulted in an obvious cell cycle arrest at the $G_{0} / G_{1}$ phase with a concomitant decrease in the proportion of cells in the $\mathrm{S}$ and $\mathrm{G}_{2} / \mathrm{M}$ phases in cell cycle distribution (Fig. 1).

Bufalin induces cell apoptosis in BEL-7402/5-FU cells. Induction of apoptosis in BEL-7402/5-FU cells by bufalin at a nanomolar concentration was confirmed in the present study. Quantitative assessment of apoptosis by Annexin V/ PI staining showed that treatment with $1 \mathrm{nM}$ bufalin for $24 \mathrm{~h}$ significantly increased the early apoptosis rates from 6.8 to $19.3 \%(\mathrm{P}=0.002)$ in BEL-7402/5-FU cells (Fig. 2A and B). Obvious apoptosis was also observed using confocal microscopy following bufalin treatment (Fig. 2C and D).

Bufalin decreases the drug efflux pump activity in $B E L-7402 / 5-F U$ cells. The effect of bufalin on drug efflux pump activity in BEL-7402/5-FU cells was evaluated by quantification of intracellular ADM fluorescence. As shown in Fig. 3, the intracellular ADM intensity in BEL-7402/5-FU cells after bufalin treatment increased significantly when compared to the control $(\mathrm{P}=0.004)$, which indicated that the drug efflux pump activity was attenuated by bufalin. The intracellular retention of Rh-123, a functional index of P-gp activity, was also determined. Although the Rh-123 intensity in bufalin-treated BEL-7402/5-FU cells was slightly lower than that in the control, no significant difference was found between them $(\mathrm{P}>0.05)$. The results suggest that the activity of P-gp may be of little importance in the reversal effect of bufalin. Additionally, the intracellular accumulation of FLU, a functional index of MRP1 activity, was analyzed. As opposed to Rh-123, the intracellular FLU was significantly enhanced in bufalin-treated BEL-7402/5-FU cells when compared to the control $(\mathrm{P}<0.001)$ which indicated that activity of MRP1 was markedly inhibited by bufalin (Fig. 3). Bufalin decreased the drug efflux pump activity in BEL-7402/5-FU cells via inhibition of MRP1 but not P-gp.

Bufalin downregulates the expression of TS, MRPI and the ratio of $\mathrm{Bcl}-x \mathrm{~L} / \mathrm{Bax}$. To further clarify the possible mechanisms related to the reversal effect on MDR by bufalin, the expression of several genes involved with MDR of BEL-7402/5-FU cells was quantified by both real-time PCR and western blot analysis. As shown in Fig. 4, the expression levels of TS, MRP1 and Bcl-xL mRNAs, were significantly downregulated while Bax mRNA was greatly upregulated by bufalin $(\mathrm{P}<0.05)$. Particularly, the ratio of $\mathrm{Bax} / \mathrm{Bcl}-\mathrm{xL}$ in bufalin-treated BEL-7402/5-FU cells exhibited an increase of nearly 20-fold compared to the control cells. However, no change in the mRNA expression of MDR1 was noted after bufalin treatment $(\mathrm{P}>0.05)$. Similar findings were found in our results using western blot analysis on protein levels (Fig. 5). Collectively, these results suggest that bufalin strengthens the efficacy of 5-FU through inhibiting expression of TS, increasing the intracellular drug concentration via reducing the expression/activity of MRP1, inducing apoptosis by regulating apoptosis-related genes and increasing the ratio of Bax/Bcl-xL consequently resulting in an extensive enhancement of the chemosensitivity of BEL-7402/5-FU cells to 5-FU.

\section{Discussion}

Chemotherapy with cytotoxic drugs plays an essential role in the management of most malignant tumors. However, chemotherapy of HCC often results in intolerable toxicity to HCC patients who usually suffer from concomitant cirrhosis; and thus has been of limited use in clinical practice (3). Moreover, 
A
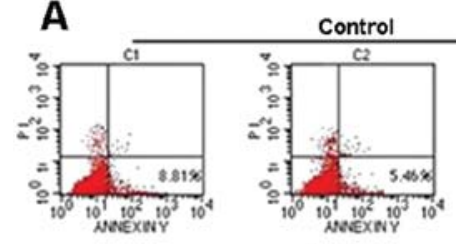

Bufalin
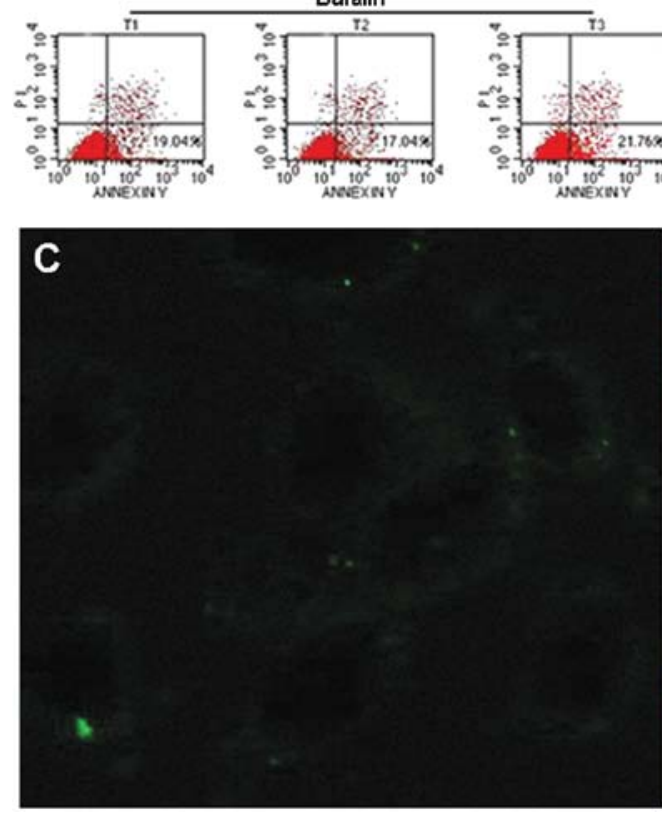

B

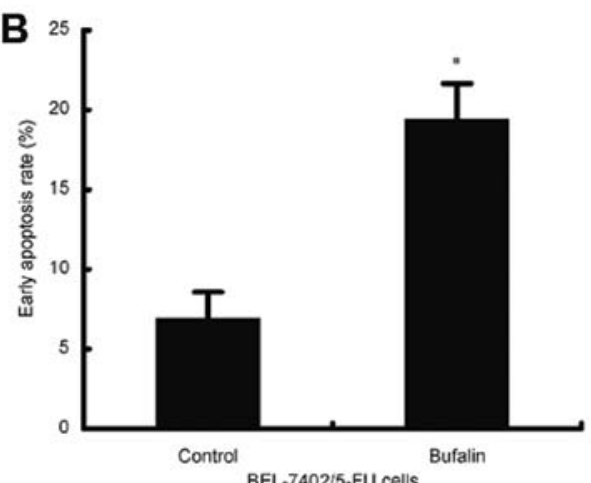

D

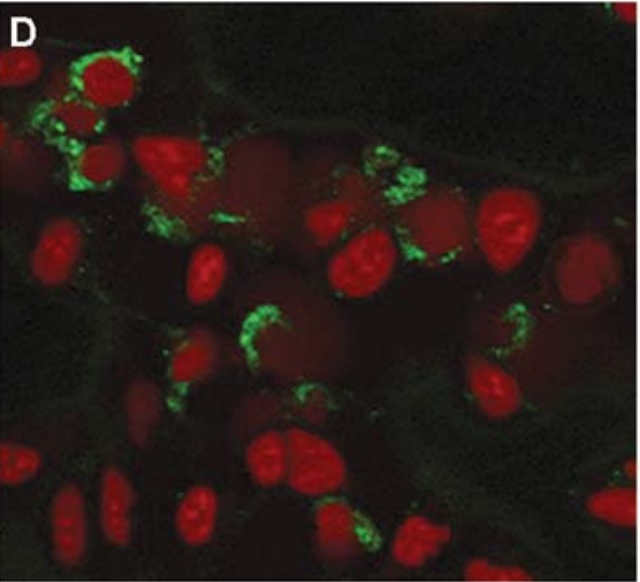

Figure 2. Bufalin induces cell apoptosis in BEL-7402/5-FU cells. (A) Representative samples assessed by Annexin V/PI staining with flow cytometry. (B) Quantification of the induction of apoptosis by bufalin. Bufalin significantly increased the early apoptosis rates from 6.8 to $19.3 \%$ (" $\mathrm{P}=0.002$ ) in BEL7402/5-FU cells. Compared to (C) the control cells, (D) obvious apoptosis was observed in cells using confocal microscope after bufalin treatment.

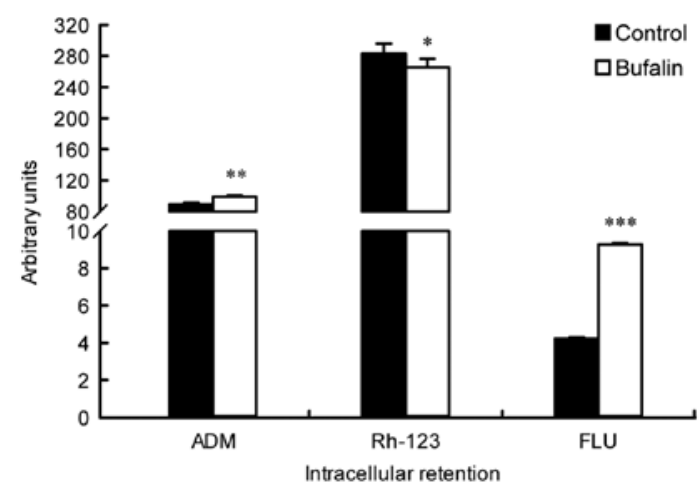

Figure 3. Bufalin decreases the drug efflux pump activity in BEL-7402/5-FU cells. The drug efflux pump activity, P-gp and MRP1 activity in bufalintreated BEL-7402/5-FU cells were compared to the control cells by quantification of intracellular ADM fluorescence, retention of Rh-123 and accumulation of FLU, respectively. The intracellular ADM intensity in the bufalin-treated BEL-7402/5-FU cells was significantly increased when compared to the control $\left({ }^{* *} \mathrm{P}=0.004\right)$. The Rh-123 intensity in the bufalin-treated BEL-7402/5-FU cells was slightly lower than that in the control, but no significant difference was found ( $\mathrm{P}=0.147)$. The intracellular accumulation of FLU was greatly increased in the bufalin-treated BEL-7402/5-FU cells when compared to the control $\left({ }^{* * *} \mathrm{P}<0.001\right)$. Values were calculated by the Student's t-test. All data are presented as means \pm SD. ADM, adriamycin; Rh-123, Rhodamine 123; FLU, fluorescein.

even for HCC patients with satisfactory liver function, only a small percentage of patients gain benefits due to intrinsic or acquired chemoresistance. In particular, HCC cells universally

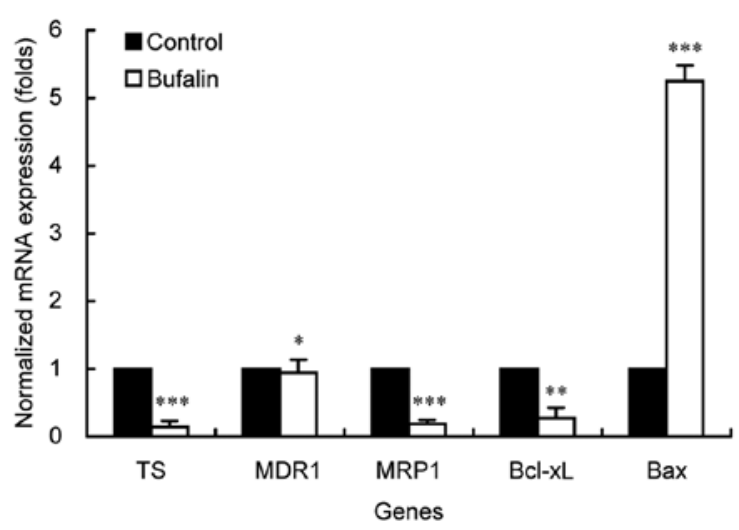

Figure 4. Effect of bufalin on the mRNA expression of genes involved in the MDR of BEL-7402/5-FU cells. Relative mRNA expression was normalized to $\beta$-actin and estimated by the method of $2^{-\Delta \Delta C t}$. No significant change was noted in MDR1 mRNA ( $\mathrm{P}=0.632$ ), while the expression of TS, MRP1 and Bcl-xL mRNAs was significantly downregulated and Bax mRNA was highy upregulated by bufalin $\left({ }^{* *} \mathrm{P}=0.001,{ }^{* * *} \mathrm{P}<0.001\right)$. Values were calculated by the Student's t-test. All data are presented as means \pm SD.

present an MDR phenotype immediately after initial chemotherapy; and therefore, HCC is generally deemed refractory to cytotoxic drugs (4). Therefore, reversing MDR has been a major challenge for the success of chemotherapy for HCC. Screening effective chemosensitizers or MDR reversal agents, and combining them with cytotoxic drugs (fluoropyrimidines, anthracyclines, platinum complexes) has been a promising 
A

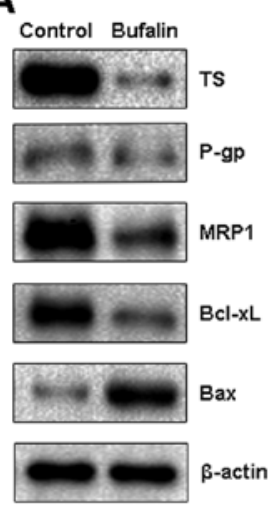

B

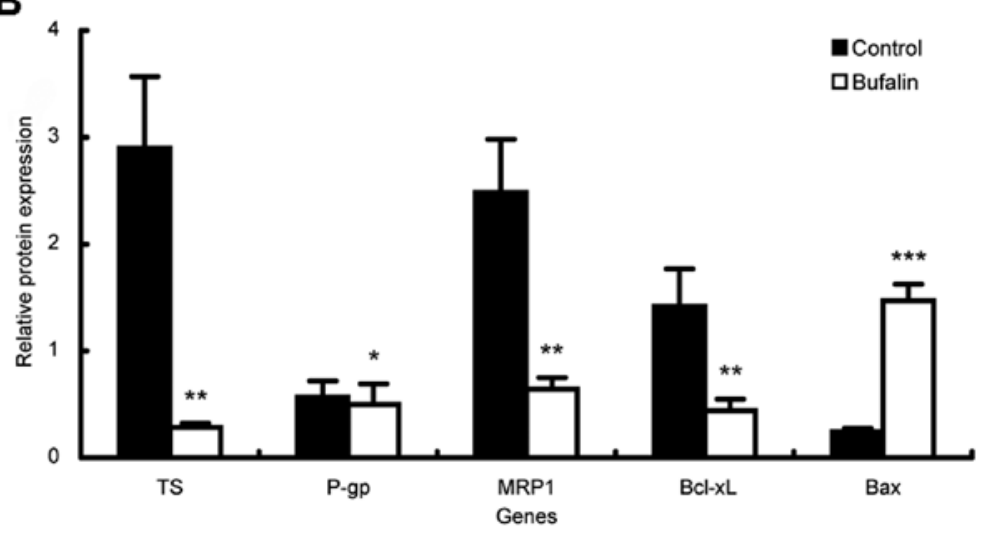

Figure 5. Effect of bufalin on the expression of proteins involved in the MDR of BEL-7402/5-FU cells. (A) Representative western blot analysis. (B) Quantitative evaluation of the relative protein expression normalized to $\beta$-actin intensity. No significant change was noted in $\mathrm{P}$-gp $\left({ }^{*} \mathrm{P}=0.663\right)$, while the expression of TS, MRP1 and Bcl-xL was significantly downregulated $\left({ }^{* *} \mathrm{P}=0.002,0.003\right.$ and 0.010 , respectively) and the Bax protein was highly upregulated by bufalin $\left({ }^{* * *} \mathrm{P}<0.001\right)$. Values were calculated by the Student's t-test. All data are presented as means \pm SD.

strategy to overcome MDR and thereby successful management of HCC may be achieved (15).

In the past several decades, great efforts have been made to develop and screen compounds or substances to reverse MDR. A few compounds, such as verapamil, cyclosporins, quinidine and tamoxifen, have shown MDR reversal activity to some extent in vitro (16). However, these compounds often cause severe toxicity such as heart failure and immunosuppression resulting in disappointing clinical results (16). In recent years, several natural products extracted from Chinese traditional medicine have been proposed as MDR reversal agents for multidrug resistant leukemia (17), and cancers of the breast (18), lung (19), colon (17,20) and pancreas (21). For HCC, pheophorbide A from Scutellaria barbata (22), dioscin from Dioscorea nipponica Makino (23), schizandrin A from the Fructus schizandrae (24), and Schisandrol A from Schisandra chinensis (25), have shown encouraging reversal activity in vitro or in vivo. These findings indicate that natural products isolated from Chinese traditional medicine are promising sources of novel MDR reversal agents and warrant further research.

Bufalin, an active ingredient of the traditional Chinese medicine 'Chansu', has been proven to be a potent inducer of differentiation in human leukemia cells (9). Moreover, it can induce apoptosis in human leukemia and a large range of solid tumor cells (10-13). Recently, several studies have reported that bufalin suppresses the proliferation of prostate and bladder cancer, osteosarcoma, choriocarcinoma, endometrial and ovarian cancer, and colon cancer in vitro, and this activity has been associated with potent cytotoxicity to human tumor cells through pathways related to apoposis, cell cycle arrest and autophagy, following treatment alone or in combination $(11,26$ 31). However, these findings were observed when fubalin was administered at a cytotoxic dose, yet, the effect of bufalin on MDR when it is administered at a non-cytotoxic concentration remains unknown. The present study was, therefore, designed to examine the potential reversal activity of bufalin and reveal the possible mechanisms.

In the present study, a concentration of $1 \mathrm{nM}$ which was much less than the $\mathrm{IC}_{10}$ at $48 \mathrm{~h}(1.7 \mathrm{nM})$ was used as the reversal concentration of bufalin. Based on the MTT assay, treatment with $1 \mathrm{nM}$ bufalin did not show any significant cytotoxic effect on BEL-7402/5-FU cells. Under such a low dosage, bufalin indeed enhanced the chemosensitivity of BEL-7402/5-FU cells to 5-FU with a RF of 3.8-fold which was similar to that of $1 \mu \mathrm{M}$ verapamil (3.1-fold). To the best of our knowledge, this is the first study to demonstrate the reversal effect of bufalin on MDR in cancer chemotherapy.

To explore the mechanisms involved in the reversal effects of bufalin on MDR of BEL-7402/5-FU cells, alterations in cell cycle distribution, apoptosis rate, drug efflux pump activity, and the expression of TS, P-gp, MRP1, Bcl-xL and Bax, were determined following treatment with $1 \mathrm{nM}$ bufalin. Firstly, our results showed that bufalin significantly arrested the BEL-7402/5-FU cells at the $\mathrm{G}_{0} / \mathrm{G}_{1}$ phase and the cells could not enter cell cycle progression and died via the apoptosis pathway. This finding was supported by previous findings that bufalin at the same concentration $(1 \mathrm{nM})$ arrested the cell cycle in endometriotic stromal cells at the $G_{0} / G_{1}$ phase and in human leukemia cells at the $\mathrm{G}_{2} / \mathrm{M}$ phase $(32,33)$. It has been reported that the persistent activation of MAP kinase in response to bufalin was one of the signal transduction pathways involved in bufalin-induced apoptosis (34). Particularly, bufalin induced marked apoptosis in human HCC HepG2 cells via both the Fas- and mitochondrial-mediated pathways, and a Fas-mediated caspase-10-dependent pathway may play a crucial role (35). However, in the BEL-7402/5-FU cells treated with bufalin, downregulation of Bcl-xL and the upregulation of Bax and a large increase in the ratio of $\mathrm{Bax} / \mathrm{Bcl}-\mathrm{xL}$ were confirmed in the present study, which contributed to the resensitivity of BEL-7402/5-FU cells to 5-FU. These results were similar to the findings in human gastric cancer MGC803 cells and our previous study in vivo $(12,13)$. Secondly, the drug efflux pump activity of BEL-7402/5-FU cells was significantly attenuated by $1 \mathrm{nM}$ bufalin. As shown in Figs. 3-5, the activity and expression of MRP1 but not P-gp was greatly inhibited. The successful inhibition of the specific ATP-binding cassette transporter in the present study led to a significant reversal of MDR. Additionally, bufalin markedly downregulated the expression of TS, a rate-limiting enzyme in DNA biosynthesis 
and the primary target of 5-FU (36), which also contributed to the enhanced chemosensitivity of BEL-7402/5-FU cells.

In conclusion, the present study confirmed the reversal effect of bufalin on MDR in multidrug-resistant HCC cells at a low nanomolar concentration. Bufalin at a non-cytotoxic dose arrested the cell cycle at the $G_{0} / G_{1}$ phase, induced apoptosis through an increase in the $\mathrm{Bax} / \mathrm{Bcl}-\mathrm{xL}$ ratio, inhibited the drug efflux pump activity via downregulation of MRP1 and reduced the expression of TS in BEL-7402/5-FU cells. Our results suggest that bufalin can effectively reverse the MDR in HCC cells through multiple pathways. Thus, the combination of bufalin with cytotoxic drugs may serve as a promising strategy for the chemotherapy of HCC.

\section{Acknowledgements}

The present study was supported by grants from the National Natural Science Foundation of China (no. 30600814) and the 'Qimingxing' Plan for Young Scientists, Shanghai Municipal Science and Technology Commission (no. 08QA14003).

\section{References}

1. Ferlay J, Shin HR, Bray F, Forman D, Mathers C and Parkin DM: GLOBOCAN 2008, Cancer Incidence and Mortality Worldwide: IARC CancerBase No. 10 [Internet]. International Agency for Research on Cancer. Lyon, France, 2010 [http://globocan.iarc.fr].

2. Marin JJ, Romero MR and Briz O: Molecular bases of liver cancer refractoriness to pharmacological treatment. Curr Med Chem 17: 709-740, 2010.

3. Zhu AX: Systemic therapy of advanced hepatocellular carcinoma: how hopeful should we be? Oncologist 11: 790-800, 2006.

4. Thomas MB, O'Beirne JP, Furuse J, Chan AT, Abou-Alfa G and Johnson P: Systemic therapy for hepatocellular carcinoma: cytotoxic chemotherapy, targeted therapy and immunotherapy. Ann Surg Oncol 15: 1008-1014, 2008.

5. Kim JH, Chung JB, Park IS, et al: Combined use of tamoxifen, cyclosporin A, and verapamil for modulating multidrug resistance in human hepatocellular carcinoma cell lines. Yonsei Med J 34: 35-44, 1993.

6. Ferry DR, Traunecker H and Kerr DJ: Clinical trials of P-glycoprotein reversal in solid tumours. Eur J Cancer 32A: 1070-1081, 1996.

7. Thomas $\mathrm{H}$ and Coley HM: Overcoming multidrug resistance in cancer: an update on the clinical strategy of inhibiting p-glycoprotein. Cancer Control 10: 159-165, 2003.

8. Meng Z, Yang P, Shen Y, et al: Pilot study of huachansu in patients with hepatocellular carcinoma, non-small-cell lung cancer, or pancreatic cancer. Cancer 115: 5309-5318, 2009.

9. Zhang LS, Nakaya K, Yoshida T and Kuroiwa Y: Bufalin as a potent inducer of differentiation of human myeloid leukemia cells. Biochem Biophys Res Commun 178: 686-693, 1991.

10. Watabe M, Ito K, Masuda Y, Nakajo S and Nakaya K: Activation of AP-1 is required for bufalin-induced apoptosis in human leukemia U937 cells. Oncogene 16: 779-787, 1998.

11. Yeh JY, Huang WJ, Kan SF and Wang PS: Effects of bufalin and cinobufagin on the proliferation of androgen-dependent and -independent prostate cancer cells. Prostate 54: 112-124, 2003.

12. Li D, Qu X, Hou K, et al: PI3K/Akt is involved in bufalin-induced apoptosis in gastric cancer cells. Anticancer Drugs 20: 59-64, 2009.

13. Han KQ, Huang G, Gu W, Su YH, Huang XQ and Ling CQ: Anti-tumor activities and apoptosis-regulated mechanisms of bufalin on the orthotopic transplantation tumor model of human hepatocellular carcinoma in nude mice. World J Gastroenterol 13: 3374-3379, 2007.

14. Gu W, Fang FF, Li B, Cheng BB and Ling CQ: Characterization and resistance mechanisms of a 5-fluorouracil-resistant hepatocellular carcinoma cell line. Asian Pac J Cancer Prev 13: 4807-4814, 2012.
15. Shi LX, Ma R, Lu R, et al: Reversal effect of tyroservatide (YSV) tripeptide on multi-drug resistance in resistant human hepatocellular carcinoma cell line BEL-7402/5-FU. Cancer Lett 269: 101-110, 2008.

16. Robert J and Jarry C: Multidrug resistance reversal agents. J Med Chem 46: 4805-4817, 2003.

17. Ramachandran C, Rabi T, Fonseca HB, Melnick SJ and Escalon EA: Novel plant triterpenoid drug amooranin overcomes multidrug resistance in human leukemia and colon carcinoma cell lines. Int J Cancer 105: 784-789, 2003.

18. Ravizza R, Gariboldi MB, Molteni R and Monti E: Linalool, a plant-derived monoterpene alcohol, reverses doxorubicin resistance in human breast adenocarcinoma cells. Oncol Rep 20: 625-630, 2008

19. Xu M, Sheng LH,Zhu XH,Zeng SB and Zhang GJ: Reversal effect of Stephania tetrandra-containing Chinese herb formula SENL on multidrug resistance in lung cancer cell line SW1573/2R120. Am J Chin Med 38: 401-413, 2010.

20. Han Y, Bu LM, Ji X, Liu CY and Wang ZH: Modulation of multidrug resistance by andrographolid in a HCT-8/5-FU multidrug-resistant colorectal cancer cell line. Chin J Dig Dis 6: 82-86, 2005.

21. Borska S, Sopel M, Chmielewska M, Zabel M and Dziegiel P: Quercetin as a potential modulator of P-glycoprotein expression and function in cells of human pancreatic carcinoma line resistant to daunorubicin. Molecules 15: 857-870, 2010.

22. Tang PM, Chan JY, Zhang DM, et al: Pheophorbide a, an active component in Scutellaria barbata, reverses P-glycoproteinmediated multidrug resistance on a human hepatoma cell line R-HepG2. Cancer Biol Ther 6: 504-509, 2007.

23. Sun BT, Zheng LH, Bao YL, Yu CL, Wu Y, Meng XY and Li YX: Reversal effect of Dioscin on multidrug resistance in human hepatoma HepG2/adriamycin cells. Eur J Pharmacol 654: 129-134, 2011.

24. Huang M, Jin J, Sun H and Liu GT: Reversal of P-glycoproteinmediated multidrug resistance of cancer cells by five schizandrins isolated from the Chinese herb Fructus Schizandrae. Cancer Chemother Pharmacol 62: 1015-1026, 2008.

25. Fong WF, Wan CK, Zhu GY, Chattopadhyay A, Dey S, Zhao Z and Shen XL: Schisandrol A from Schisandra chinensis reverses P-glycoprotein-mediated multidrug resistance by affecting Pgp-substrate complexes. Planta Med 73: 212-220, 2007.

26. Yu CH, Kan SF, Pu HF, Jea Chien E and Wang PS: Apoptotic signaling in bufalin-and cinobufagin-treated androgen-dependent and -independent human prostate cancer cells. Cancer Sci 99: 2467-2476, 2008.

27. Hong $\mathrm{SH}$ and Choi $\mathrm{YH}$ : Bufalin induces apoptosis through activation of both the intrinsic and extrinsic pathways in human bladder cancer cells. Oncol Rep 27: 114-120, 2012.

28. Yin JQ, Shen JN, Su WW, et al: Bufalin induces apoptosis in human osteosarcoma U-2OS and U-2OS methotrexate300resistant cell lines. Acta Pharmacol Sin 28: 712-720, 2007.

29. Takai N, Ueda T, Ishii T, et al: Effects of bufalin on the proliferation of human choriocarcinoma cells. Int J Gynecol Cancer 21: 1105-1109, 2011.

30. Takai N, Ueda T, Nishida M, Nasu K and Narahara H: Bufalin induces growth inhibition, cell cycle arrest and apoptosis in human endometrial and ovarian cancer cells. Int J Mol Med 21: 637-643, 2008.

31. Xie CM, Chan WY, Yu S, Zhao J and Cheng CH: Bufalin induces autophagy-mediated cell death in human colon cancer cells through reactive oxygen species generation and JNK activation. Free Radic Biol Med 51: 1365-1375, 2011.

32. Nasu K, Nishida M, Ueda T, Takai N, Bing S, Narahara H and Miyakawa I: Bufalin induces apoptosis and the G0/G1 cell cycle arrest of endometriotic stromal cells: a promising agent for the treatment of endometriosis. Mol Hum Reprod 11: 817-823, 2005.

33. Jing Y, Watabe M, Hashimoto S, Nakajo S and Nakaya K: Cell cycle arrest and protein kinase modulating effect of bufalin on human leukemia ML1 cells. Anticancer Res 14: 1193-1198, 1994.

34. Watabe M, Masuda Y, Nakajo S, Yoshida T, Kuroiwa Y and Nakaya K: The cooperative interaction of two different signaling pathways in response to bufalin induces apoptosis in human leukemia U937 cells. J Biol Chem 271: 14067-14072, 1996.

35. Qi F, Inagaki Y, Gao B, et al: Bufalin and cinobufagin induce apoptosis of human hepatocellular carcinoma cells via Fas- and mitochondria-mediated pathways. Cancer Sci 102: 951-958, 2011.

36. Zhang N, Yin Y, Xu SJ and Chen WS: 5-Fluorouracil: mechanisms of resistance and reversal strategies. Molecules 13: 1551-1569, 2008. 